\title{
Research Trends: Natural Products as Pest, Microbial Disease as Tumour Control Agents
}

\author{
Majekodunmi O. Fatope, Salma M. Z. Al-Kindi and Abdulrahman O. Abdulnour
}

Plant Chemistry Research Group, Chemistry Department, College of Science, Sultan Qaboos University, P.O. Box 36, Postal Code 123, Al-Khod, Muscat, Sultanate of Oman, magek @ squ.edu.om.

\section{النبلتا اللمبية كمواد المحارية الآلت الزراعية ، ولأمرالن الميكروبة ولأورلم}

\section{ماجكودوني فلتوي سسلف الكنهي و عبدالرحمن عبدالنور}

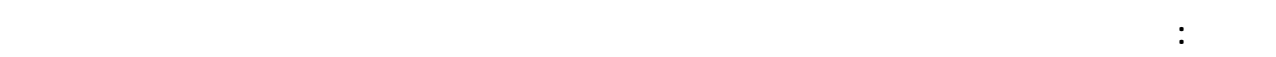

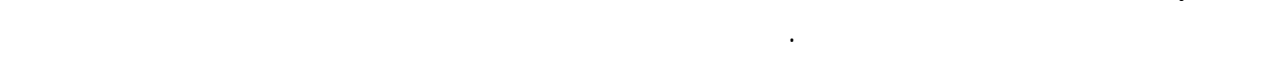

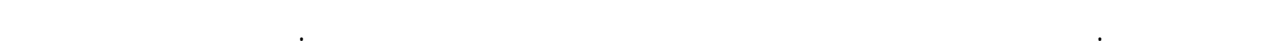

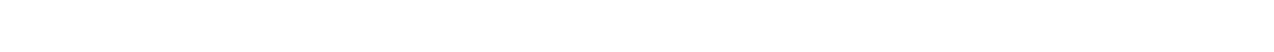
ششطظها العلاجي والإختبار الأحيائي اللازم للتعرف عليها.

\begin{abstract}
The zeal to conquer human, agronomic, and veterinary diseases or pests has always sustained research interests directed at finding new medications from under explored biodiversity. The adoption of bioassay methods, which correlate with prevention, inhibition and reversal of diseases or elimination of pests, in screening natural products for bioactive compounds is critical to the discovery of new medications. This article focuses on areas of natural products chemistry that connect academia with industry. It discusses the technical skills needed to find bioactive compounds from microbes, marine invertebrates, plants and insects, highlighting the mode of action of selected bioactive compounds and bioassay models for detecting them. It also reviews methods and prospects of genetic manipulation of organisms to produce unnatural natural products of therapeutic importance.
\end{abstract}




\section{FATOPE, AL-KINDI and ABDULNOUR}

\section{CONTENTS}

1. Introduction

2. Screening for Bioactive Natural Products $\quad 57$

3. Metabolites from Microbial Sources $r$

$\begin{array}{ll}3.1 & \text { Antibacterial Agents }\end{array}$

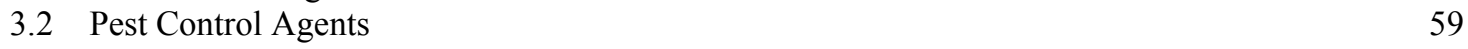

$\begin{array}{ll}3.3 & \text { Biocontrol Agents } \\ \end{array}$

4. Metabolites from Marine Organisms $\quad 60$

$\begin{array}{lr}\text { 5. Metabolites from Plants } & 61\end{array}$

$\begin{array}{lll}5.1 & \text { Insecticides } & 61\end{array}$

\begin{tabular}{ll}
5.2 & Antimicrobials \\
\hline
\end{tabular}

$\begin{array}{ll}5.3 & \text { Antitumor Agents } \\ 5.4 & 62\end{array}$

$\begin{array}{lll}5.4 & \text { Cancer Chemoprevention } & 63\end{array}$

6. Metabolites from Arthropods $\quad 63$

7. Genetic Manipulation of Organisms for Bioactive Metabolites 64

$\begin{array}{lll}7.1 & \text { Method for expressing foreign genes in microbes } & 64\end{array}$

$\begin{array}{ll}7.2 & \text { Methods for expressing foreign genes in plants } \\ \end{array}$

7.2.1 Use of Autonomously Replicating Virus as Vectors $\quad 65$

7.2.2 Agrobacterium-Mediated Gene Transfer $\quad 65$

7.2.3 'Shot gun' or Biolistic Gene Transfer $\quad 66$

8. Conclusions $\quad 66$

9. Acknowledgement $\quad 67$

$\begin{array}{lr}\text { 10. References } & 67\end{array}$

\section{Introduction}

The geo-ecological conditions that support life on Earth vary from moderately wet and warm to extremely arid, hot or cold terrestrial environments, and from fresh waters to salty, acidic or alkaline aquatic habitats. Organisms in different environments produce non-nutritional compounds called natural products or secondary metabolites. Natural products are formed from a handful of diverse and universally present precursors such as acetyl-CoA, amino acids or shikimates through an intricate web of enzymecatalyzed reactions (Herbert 1989). The significance of natural products in the life of producing organism remains obscure. Some natural products appear to protect the organisms from predators, diseases and challenges of hostile environment. Others display biological activity with potential pharmaceutical and agricultural uses. Several of them have no known uses. A plethora of natural products has been isolated from plants throughout the known history of humans, and within the last 50 years from marine organisms, arthropods, amphibians, fungi and bacteria. Taken together, natural products have occupied a commanding position among drugs that are now used against agronomic pests, infective organisms, parasites of livestock and humans, and diseases such as cancer and malaria. They have also found useful applications in food and fragrance industry as flavoring agents. Natural products compliment synthetic chemicals as a source of pharmaceuticals. Structurally, natural products show little overlap with synthetic products. They could however be as toxic as synthetic chemicals. When used as crop protection agents, they are environmentally friendly. Their biodegradation by soil microorganisms and re-integration into the environment are readily achieved.

In establishing a research strategy that is natural products-based, the aims of the investigation must be well defined. In academia and industry, there are 3 broad reasons for scientific investigations in the area of natural products. They are 1) to find biologically active compounds. Research plans are approved for bioactivity-driven isolation and identification of secondary metabolite if initial extracts (of plants, 


\section{RESEARCH TRENDS IN NATURAL PRODUCTS}

arthropods, and broth) showed useful biological activity. In such a case a reliable bioassay is needed for success. 2) To screen transgenic organism for a single metabolite of commercial importance. An elaborate isolation scheme may be undesirable, but a selective and sensitive detection method using the best of analytical tools may be important. This is, in principle, a natural extension of the first objective with biotechnology skills playing a major role. 3) For re-classification of a confused phylogeny. Secondary metabolites from each species of a genus are elaborately isolated, characterized and compared with one another. The first two objectives are the most important to pharmaceutical companies, grant awarding agencies and research establishments interested in natural products. The biological and pharmacological profiles of potentially useful bioactive metabolites are compiled to determine their safety, competitiveness and patentability. Information is also gathered on how bioactive metabolites can be produced on a largescale through studies of biosynthetic pathways and the molecular biology of the producing organism. A good understanding of these parameters will enable scientists to manipulate secondary metabolism, shift secondary metabolic pathways within plant species and microbial strains and turn crops or microbes into flexible chemical factories or bioreactors. Studies of secondary metabolites at the molecular level have been slow because of the complex pathways of secondary metabolism in higher organisms, and the absence of suitable genetic systems. The key to this may well be in genomic revolution, informatics and high throughput screening.

This article will provide a realistic review from application perspectives, sustainable research trends in natural products within the academia - industry interface, and elaborate on the opportunities and difficulties embedded in the exploitation of natural products. In this report, natural product is defined to include compounds isolated from microbes, marine organisms, arthropods, plants, and biocontrol agents, and also compounds obtained from manipulated biosynthetic pathways.

\section{Screening for Bioactive Natural Products}

There has been growing interest within academia and pharmaceutical industries in bioactive natural products and the molecular basis of their activity. The hitherto common practice of phytochemists to isolate, characterize and publish phytocompounds without regard to bioactivities is no longer attractive to academic journals and funding agencies. Three technologies are required for sourcing bioactive compounds. They are separation methods (Martson and Hostettmann 1991; Van Beek 1999), structural elucidation (Massiot et al. 1999) and bioassay methods (Fatope 1995, Dey et al. 1991). Bioassay technology for finding bioactive compounds has undergone major changes during the past decade. Bioassay methods may be grouped into two: the in vivo model that involves the use of whole or target organisms, and the in vitro model that is enzyme, receptor, mode of action or mechanism-based. Genomes now provide ever-increasing tool and platform for designing novel in vitro assay models, with new targets emerging for insecticides, herbicides, anti-infective and antitumor compounds. In vitro model is used as an ancillary screen to supplement primary in vivo screens. In the domain of pharmacology, a desired objective is to extrapolate data from in vitro experiments to in vivo models.

Many discoveries in the 1980 s relied on in vivo models. There are quite a number of them used to detect anti-infective, antitumor, insecticidal and herbicidal agents (Fatope, 1995; Dey et al. 1991). In vivo models are now miniaturized for certain evaluations. They are less costly, easier to perform and more adaptable for natural product screenings. Tests on whole organisms by nature are broad based and embrace multiple targets, unlike tests on in vitro models, which are target-specific. Most pharmaceutical companies in the late 1990s have adopted mechanism-based in vitro assays that employ receptor binding or enzyme inhibition protocols on normal or transformed cell lines of animals, humans or plants. Receptor-based assays involve the following general steps:

- $\quad$ Docking of test molecules to receptors that are connected to the response element of DNA.

- Activation or inhibition of the expression of certain proteins mediating biological responses by compound - receptor - DNA association. 


\section{FATOPE, AL-KINDI and ABDULNOUR}

Biological response that may be beneficial or detrimental depending on dosage.

Receptor-based assays allow the design of cellular high throughput screening procedures. They are often expensive, sophisticated, specific, automated and may require in several cases a dedicated research technician.

The adoption of receptor-based in vitro models for plant chemistry work may require a robust combination of several expensive assays. Plant extracts are a complex library of chemical compounds, which are structurally and pharmacologically dissimilar. Many potentially useful compounds in plant extracts are not detected in in vitro screens because the assays are too specific or because of interactions that occur among the components of extracts. A number of enzyme or receptor-based bioassays are very sensitive to phytosterols, tannins and saponins which are commonly encountered in plant extracts, and anionic polysaccharides found in marine organisms. It is thus a standard practice to subject extracts to chemical or biological dereplication protocols to eliminate compounds that could interfere with assay results. NCI uses solid phase extraction cartridges for dereplication of tannins in aqueous extract, (Cardellina et al. 1993; Cordell 1995) or direct chromatography on Sephadex G-25 or polyamide columns. Anionic polysaccharides are precipitated from aqueous solution with equal volume of ethanol (Cardellina et al. 1993). In vitro tests are routinely used to monitor the activity of fermentation and combinatorial synthesis products where structural differences between products are less contrasting. Pure compounds or crude extracts that fail the in vivo test will face a formidable challenge, irrespective of the observed level of activity in vitro, in producing relevant applications.

Whatever model is adopted, screening methods must be sensitive, use a small amount of test materials, allow simple test sample preparation, give good results, have good throughput capacity, and a wide field of view. The assay output must correlate with an important function in disease etiology or microbial pathenogenicity.

\section{Metabolites From Microbial Sources}

Bacteria and fungi cause several plant, human and animal diseases. They are also common sources of novel bioactive metabolites that have found useful applications as anti-bacterial, insecticidal, nematicidal, and herbicidal agents. The bio-diversity of microbes is immense. The metabolites they produce can be manipulated by changing the composition of the growth media, by combinatorial biosynthesis and 'shot gun' cloning of their DNA. These manipulations can be conducted with relative ease on prokaryotes, for example bacteria, because their genetic materials are contained in cytoplasmic chromosomes. It is more difficult to achieve the same level of success with organisms whose genetic materials are packaged in chromosomes located in the nucleus, the eukaryotes e.g., yeast, filamentous fungi and higher organisms.

There are roughly three domains of microbial life on Earth: the archeae, eubacteria and eukaryotes. Microbes that love moderate environments are called mesophiles. Several of them are culturable. Mesophilic soil microorganisms, the actinomycetes, for example, have been and remain a major source of novel microbial metabolites (Deyfuss et al. 1994). The discovery of bioactive compounds usually begins with isolation and identification of the microbes and growing them in a dish on appropriate media. The chemicals they produce are scaled-up by fermentation. The fermentation broth is extracted, fractionated, tested and purified. Typically, mesophilic bacteria and yeast can be cultivated on standard Mueller - Hinton agar or diagnostic sensitivity test agar (DST). Testing is usually performed using the traditional wholeorganism based dilution, diffusion and bioautographic assay methods. These methods have been adequately reviewed by Rios et al. (1988). Kavanagh (1963) has also suggested the principles and limitations of antimicrobial in vivo assays. In recent years receptor-based in vitro assays have become increasingly popular for screening fermentation broth in the industry. As an illustration, Merck scientists isolated the fungus Pseudomassaria from a plant collected from a forest near Kinshasha in the Democratic Republic of Congo. Its fermentation broth was extracted, fractionated and screened against a receptor-based assay, 


\section{RESEARCH TRENDS IN NATURAL PRODUCTS}

which monitors agents that interact with and activate the insulin receptors. This led to isolation of compound L-73281 with insulin-like properties (Zhang et al. 1999).

Over the past 3 decades, scientists have collected and identified microbes that flourish in extreme environments. They include microbes from extremely hot (thermopiles, e.g., from hydrothermal vents), cold (pschrophiles, e.g., from The Antarctica), acidic (acidophiles, e.g., from volcanic pools, abandoned coal mines or sour petroleum wells), salty waters (halophiles, e.g., from salty water of the Dead Sea in the Middle East), alkaline pools (alkalophiles, e.g., from Kenya soda filled Lake Magadi), high pressure regions (barophiles, e.g., from ocean floor) and from niches with above normal level of radiation. Microbes that live in extreme environments are called extremophiles. Most extremophiles are difficult to culture, yet they contain genetic materials that could code for and produce secondary metabolites that are medicinally useful. A number of them produce enzymes that have found useful applications in the biodegradation of chemical warfare agents (Mulbry and Rainina 1999). Roughly 1/3 of drugs comes from 5\% of microbes that can be cultured. Advances in molecular biology are making genetic information that is potentially locked-up in these microbes accessible (see Section 7.1).

\subsection{Antibacterial Agents}

Several research centers and pharmaceutical industries are screening broths and extracts of fermentation in a battery of assays, searching for natural products that could conquer new and re-emerging infectious diseases. The discovery of "wonder" antibiotics of the 1940s and 1950s brought great relief to the public and clinicians. However, today we have several antibiotics that are no longer effective at hitherto known therapeutic concentrations. Streptococcus pneumonia is today untreatable with penicillin. Multipleresistant Staphylococcus aureus that is insensitive to common antibiotics is encountered in every hospital. Drug resistant strains of Mycobacterium tuberculosis and Mycobacterium avium complex reduce the life expectancy of AIDS patients.

Most of the common antibacterials are obtained from microorganisms. The aminoglycosides, gentomycin and streptomycin, are produced by Streptomycetes or Micromonospora. Chloramphenicol is a natural product isolated from the culture filtrate of Streptomyces venezuela. Oxytetracycline is produced by Streptomyces rimosus. Erythromycin is a metabolite of Streptomyces erythreus. Clindmycin is produced by Streptomyces lincolinesis. The aforementioned antibiotics exert their effects on Gram+ or Gram- bacteria that they kill or suppress by inhibiting the synthesis of proteins necessary to retain their membrane. Antibiotics such as penicillins, cephalosporins and vancomycin, which are also microbial products, exert their antibiotic effects by interfering with the biosynthesis of cell wall. Protein synthesis is essential to the survival of bacteria, and the process may be divided into 3 segments namely: chain initiation, elongation and termination. In principle, every stage in this process is a potential target for antibiotic chemotypes and in vitro assay design. Almost all medicinally useful inhibitors of protein synthesis act on the elongation stage. The chemotype docks on appropriate subunit of the bacteria ribosome, causing misreading of the bacteria genetic message. This results in the termination of the synthesis of appropriate protein by insertion of a wrong amino acid in the growing peptide chain.

A search for novel antibacterial agents with broad spectrum of activity, better biological and chemical stability, and good tolerability will continue to dominate the attention of natural product chemists.

\subsection{Pest Control Agents}

Investigations at Sankyo, Merck, Glaxo and American Cyanamid laboratories led to isolation of milbemycins and structurally related avermectins from the broths of various strains of Streptomyces (Panclatko 1998). Their structures were determined using X-ray and other spectroscopic methods. Using anthelmintic bioassay-guided fractionation, avermectins were also isolated from the filtrate culture of Streptomyces avermititis (Albers-Schonberg et al. 1977) by scientists at Merck and their structures were determined (Albers-Schonberg et al. 1981). The nemadectins, which are structural variants of milbemycin, were also isolated at American Cyanamid from Streptomyces cyanogriseus and at Glaxo from 


\section{FATOPE, AL-KINDI and ABDULNOUR}

Streptomyces thermorchaensis. Avermectins and milbemycins are effective against worms, ticks and flies. Derivatives of avermectin are sold today for treatments of animal parasites. Milbemycins are marketed as acaricides. Avermectin potentiates glutamate and GABA-gated chloride channel opening (Arena, 1995).

The spinosyns are another group of commercially successful pest control microbial metabolites. They were obtained through screening of the culture of Saccharospora spinosa, an actinomycete collected from the Caribbean island (Hoehn and Michel 1990 and Kirst et al. 1991). Spinosyns are macrocyclic lactones. Their initial insecticide activity was detected using the bench top mosquito larvicidal assay. Researchers at Eli Lilly discovered them in 1989. Spinosyns are effective against lepidopteran insects, a major field pest of cotton and vegetables. They also control diptera, aphids, mites, cockroaches and termites. Dow Elanco markets mixtures of spinosyns A and D (18:15) produced by fermentation for control of lepidopteran pests of cotton. Spinosyns exert their effect through activation of nicotinic acetycholine receptors. They also modulate GABA-gated chloride channel systems. They are environmentally compatible, and have a rapid speed of action and low mammalian toxicity.

\subsection{Biocontrol Agents}

Some bacteria are able to protect plants from soil-borne fungal pathogens (Howell and Shpanovic 1980; Keel et al. 1990; Schippers et al. 1987; Schroth and Hancock 1982; Weller 1988; Dowling and O'Gara 1994). They achieve this by producing secondary metabolites in situ on root surface that are antagonist of antibiotics, hydrolytic enzymes and siderophores (low molecular weight compounds that are produced as specific iron chelator by microorganisms) produced by infective fungus (Dowling and O'Gara 1994). It is not known why some rhizosphere bacteria or fungi produce antagonist chemicals that protect plant. Perhaps they derive some benefit from the host plant. Bacteria from the genera Pseudomonas and Burkholderia are particularly active as biocontrol agents (Ligon et al. 1999).

An antifungal agent may exert its effect by acting directly on an important function of fungus reproduction or growth. It may inhibit a function that is important to fungal pathogenicity or it may stimulate a plant defense mechanism. Most antifungal biocontrol agents belong to the first group. The technologies for culturing and isolating microbial agent from soil rhizosphere have been covered in the Hokkaido Report (Hasegawa 1986). Microbes, which have demonstrated potential as biological control agents, can also act as a source of biologically active products (Faull 1995). Some biocontrol agents have been used clinically as antifungal agents to treat skin mycoses (Tawara et al. 1989; Umio et al. 1986). For instance, pyrrolnitrin produced by Pseudomanas yrrocinna and Myxococcus flavus is active against Deutomycete, Ascomycete and Basidomycete fungus. It has been developed as a topical antimycotic drug for human uses (Tawara et al. 1989). Direct application of biocontrol agents is not wide spread in agriculture because of the difficulties of predicting the behavior of bacteria strains in the field.

\section{Metabolites From Marine Organisms}

The investigation of marine organisms for bioactive compounds started about 50 years ago, and the potential of marine organism has scarcely been explored (McConnell et al. 1994). Many marine organisms have been investigated for antitumor, antiviral and antiparasitic compounds (Faulker 1995). It has been speculated that some metabolites of marine invertebrates have their origin in microalgae which can in principle be cultured (Shimizu, 1993). In general, a large number of highly active antitumor compounds have been isolated from marine invertebrates. The best known examples include eleutherobin from Eleutherobia family of corals, sarcodictyin from Mediterranean Stolonigeran coral, the bryostatins from Bryozoan, Bugula neritine, and the dolastatins from the sea hare, Dolabell auriculata (May et al. 1987; Schmitz et al. 1993). Extracts of marine organisms being examined for antitumor compounds have been screened in a panel of about 60 human cancer cell lines in therapeutic areas of leukemia, breast, ovarian, renal, postrate, brain, colon, melanoma and lung cancers. Candidates demonstrating in vitro cytotoxicity and selectivity can then be screened in more expensive in vivo assays. There are a number of simple bench- 


\section{RESEARCH TRENDS IN NATURAL PRODUCTS}

top assays that may be adopted by smaller research groups as pre-screen or surrogate assays for antitumor activity (McLaughlin 1991; Anderson et al. 1991). Increased cell division, angiogenesis and metastasis are the major features of cancer cells. Several anticancer agents interfere with microtubule assembly in cells, making it impossible for cells to divide. They dock to tubulin, the protein that forms microtubules, thus stabilizing or depolymerizing it. Some antitumor gents interact directly with DNA leading to DNA cleavage and others inhibit topoisomerase I or topoisomerase II involved in the replication of DNA. Suffness and Pezzuto (1991) already covered bioassay methods based on different forms of carcinogenesis. Unlike antibacterial agents that explore differences between the host and invading organism to establish their effect, the structure and biochemistry of cancer cells are remarkably similar to their healthy counterparts. As a result, targets for selective destruction of cancer cells are difficult to find. At best, most antitumor agents may be selective but not specific. Many antitumor agents have more than one mode of action. A multiple mode of action could reduce resistance to drug. Compounds that demonstrate activity in the cytotoxicity assay are also known to stop cancer cells from growing by initiating responses that resemble programmed cell death. The responses are characterized by morphological changes called apoptosis (Fisher, 1994; Cohen, 1993; Steller 1995; Wyllie 1995). In apoptosis, cell shrinkage, chromatin condensation, plasma membrane ruffling and degradation of cells into apoptotic vesicles occur. Stimulus responsible for DNA damage and cytotoxic agents could induce apoptosis.

Marine organisms have also yielded antiparasitic compounds. The red algae, Digena simplex gave $\alpha-$ kainic acid that is currently marketed as an anthelmintic. It is effective against whip worm, tape worm and some round worms. Domoic acid, which is structurally related to $\alpha$-kainic acid has been isolated from red algae, Chondria armata and Alsidium corallinum. It also has anthelmintic properties. Consumption of sea foods containing domoic acid is responsible for amnesic shellfish poisoning in humans (Lundholm et al. 1994).

Very few insecticidal compounds have been sourced from marine organisms in sharp contrast to plants. The annelid, Lubriconeus heteropoda, has yielded nereistroxin from which synthetic pesticides were developed (Blunden 1996). Nereistoxin analogs have been developed and used as insecticides against coleopteran, and lepidopteran pests.

\section{Metabolites From Plants}

Plants are used extensively in rural communities as a source of medication for human, animal and agronomic diseases (Mitscher et al. 1987). Quite often, the uses of plants vary widely from one culture to another. Comprehensive reports on plants as a source of drug discovery have regularly been found in the literature in the past 10 years (Kinghorn and Balandrin 1993; Pettit et al. 1994). Roughly, 5-15\% of about 250,000 species of higher plant have been investigated systematically for bioactive compounds (Balandrin et al. 1993). Human diseases that are treated with plant materials include infections, parasitic diseases, cancer, diseases of the digestive and genito-urinary system, diabetics, malaria, etc. Preparations taken from plants are used as well against insects, microbes, nematodes and weeds.

\subsection{Insecticides}

Plant metabolites that influence behavior of insects are collectively called allelochemicals. Some of them serve as repellents, food attractants, antifeedants, feeding stimulants or anti-nutritional factors. Antifeedants are a group of highly successful allelochemicals used in insect control. They limit crop damage that may arise by feeding. They could also have direct physiological effect on pests but are not known to initiate responses that result in instant death. A prominent example is azadiractin from Neem, Azadirachta indica. Azadiractin has a complex mode of action. It is a strong insect antifeedant and growth regulator. The insecticidal potential of Neem has long been recognized and exploited in India. Some Neem insecticides are now marketed under the trade names Margosan $\mathrm{O}^{\circledR}$ and Azatin ${ }^{\circledR}$ (Knauss and Walter 1995). A number of plants that have yielded very promising antifeedants can be found in the Meliaceae, Rutaceae, 


\section{FATOPE, AL-KINDI and ABDULNOUR}

Labiatae Asteraceae, Annonacae, Malvaceae and Canellaceae families (Jacobson 1989). Allelochemicals could confer some degree of resistance on plants against pests.

Plants have an excellent record of providing novel chemicals that serve as lead compounds in the development of insecticides. Bioactive compounds from the pyrethrum plant, for instance, typically illustrate this. Extracts of the flower and head of Pyrethrum gave pyrethrin I, which is responsible for killing and pyrethrin II which, exerts knock-down activity on insects. However, these products are not stable to light and air (Pachlatko 1998). Scientists at Rothamstead Experimental Station UK, United States Department of Agriculture, Sumitomo in Japan and several other commercial concerns successfully synthesized analogs of pyrethrin (Pachlatko 1998) and developed them into multibillion dollar agrochemical businesses. The structure-activity relationships in synthetic pyrethroids are well-documented in recent reports (Elliott 1996; Henrick 1995). The pyrethroids interfere with sodium ion channels leading to prolonged opening of channels in the nerve membrane. This results in blockage of nerve signals and death in insects.

Jacobsons (1971) has reveiwed the insecticidal properties of natural products from the Compositae, Piperaceae and the Rutaceae. They are reputed to provide insecticidal dienamides like pellitorine, pipercide, dihydropipercide and guineensine. Analogs of these amides developed at Sumitoto and Wellcome Foundation (Pachlatko 1998) are very effective against weevil, rice stem borer, and housefly. The dienamides also interfere with sodium ion channels in the nerve membrane of insects.

For a plant product to be useful as an insecticide in the field, it must be active in a range of climatic conditions. Excellent performance in the green house or in the laboratory is not enough. It must be safe as determined by both scientific and political forces. It must have high insecticidal activity, low mammalian and non-target organism toxicity. Plant extracts that exert their activity by modulating the GABA receptors, voltage dependent ion channels and antagonizing acetylcholinesterase or respiratory enzymes will make good candidates for development as insecticides.

\subsection{Antimicrobials}

Plants in extreme environments like the desert are expected to have highly toxic metabolities since they have been co-existing for millennia with insects, viruses, and bacteria and fungi assaults, against which they must defend themselves (Rodriquez 1983). In several instances, it has been shown that plants respond to microbial infection, stress, biotic and abiotic elicitors by producing low molecular weight compounds called phytoalexins. Phytoalexins are usually not produced or accumulated by plants that are not under attack by diseases. Phytoalexins usually have antimicrobial or antibiotic properties (Mitscher et al. 1987). Since they are induced-defense reaction products, it is implied that phytoalexins play an important role in disease resistance. A new research direction made possible by biotechnology is to identify the genes involved in phytoalexin biosynthesis and incorporate them into plants, hoping that their expression will confer resistance on the host plant. It is known that a small family of genes that produces stilbene synthase, bibenzyl synthase and pinosylvin synthase (Hain et al. 1999, Lanz et al. 1990) are responsible for phytoalexin biosynthesis. The transfer of the entire genes and their promoters at times present very difficult biotechnological challenges. Phytoalexin genes which have been successfully transferred to plants like grapevine, rice, tobacco, tomato, potato, oil seed rape conferred disease resistance (Hain, 1993).

\subsection{Antitumor Agents}

Plants have made significant contributions to the discovery of antitumor compounds (Pettit et al. 1994). Initially, NCI started screening plants for anti-tumor activity using the leukemia model (L1210) lymphocytic leukemia in mice, sarcoma 180 in rats, and a range of carcinoma screens (Cordell, 1995; Gragg et al. 1997). Since then, antitumor assays for plant-derived compounds have undergone several changes (Suffness and Pezzuto 1991). Several discoveries from screening more than 120,000 plant extracts from over 35,000 species have been made and a number of new leads have been discovered. Plant compounds such as acronycine, aristolochic acid, bruceantin, indicine-N-oxide, lapachol, maytansine, nitidine and 


\section{RESEARCH TRENDS IN NATURAL PRODUCTS}

tylocrebrine made it to clinical phase trials and failed. Compounds such as vincristine, vinblastine, comptothecin, ellipticine and taxol (Cai et al. 1997; Mann 1992; Wall et al. 1995; Cragg et al. 1993 and Foa et al. 1994) are used in treating cancer in spite of their excessive toxicity and limited clinical efficacy. Vincristine and vinblastine affect tubulin depolymerisation, taxol stabilizes tubulin, campothecin inhibits topoisomerase I, adriamycin inhibits topoisomerase II, bleomycin cleaves DNA and 2-methyl-9-hydroxyellipticinium inhibits topoisomerase II. These plant metabolites are also useful as positive controls in mechanistic studies of new antitumor agents. NCI has recently increased her capacity to screen, to over 40,000 samples per year (Cragg et al. 1997 and 1993), compared to Glaxo Wellcome's 50,000 per day, using modern receptor-based assays that allow samples to be tested against normal and drug-resistant cell lines.

\subsection{Cancer Chemoprevention}

Cancer and HIV are the most insidious diseases confronting human race by the end of the past millennium. They are our tough adversaries in terms of mortality, morbidity and economic burden. The pathogenesis of cancer, unlike HIV, is sufficiently understood to permit development of drugs or micronutrients that can suppress, reverse or delay the carcinogenesis process. Cancer disease begins by induction of DNA mutation in a somatic cell, followed by tumorigenic expansion of cell clones, and conversion of tumor cells into benign or malignant cancer. Cells from malignant cancer can invade distant tissues and give rise to cancer subpopulations. The process of cancer metastasis is well known (Nicolson 1988; Poste and Fidler 1980). The treatment of cancer with drugs has been with us for about two decades, but the chemoprevention of cancer using herbal-based dietary agents dubbed "nutraceuticals," is a relatively new concept. Cancer chemoprevention is a biomedical science that seeks to prevent, delay or reverse the carcinogenesis process through ingestion of chemicals or dietary agents (Hong and Sporn 1997). Novel natural products from plants, demonstrating in vitro cancer chemopreventive properties, have been discovered by a team of scientists at the University of Illinois at Chicago, USA using activity-guided fractionation (Kinghorn et al. 1998). The chemopreventive agents include brassinin (Mehta et al. 1995) and resveratol (Jang et al. 1997), which are found in human herbal diets, and deguellin (Udeani et al. 1997), a naturally occurring rotenoid. There are many reports in the literature on in vitro bioassay methods for finding cancer chemopreventive agents (Lee et al. 1999 and 1998; Pezzuto 1995). Several of the bioassay methods are complex, expensive and mechanism-based. They nonetheless correlate with inhibition of physiologically significant stages in the carcinogenesis process.

\section{Metabolites From Arthropod}

The Mediterranean basin and a good portion of wet areas in the Arabian Peninsula are devoted to growing fruits and vegetables. Insects, flies and diseases transmitted by viruses, damage produce. For almost 50 years, pests have been controlled by conventional methods that involved spraying with hard insecticides. In recent years, integrated pest management is being considered, for example in the olive growing industry, as a means of reducing heavy use of insecticides whose residues are now detectable in olive oil. Integrated pest management encompasses the development of pest resistant plants, botanical insecticides, predators, parasitoids, microbial pesticides, cultural practices and semiochemicals as means of controlling pest and reducing the use of heavy insecticides.

Semiochemicals are defined as substances that transmit messages between insects, plants and animals through interaction with sensory or other forms of detection organs. They influence behavior or initiate physiological responses by acting as signals. Pheromones are a type of semiochemicals emitted by insects which affect or modify the behavior of insects of the same species (Jones 1994; Hedin et al. 1988; Hick et al. 1999). Insect pheromones have been isolated, identified and synthesized from several species of insects (Baker et al. 1980; Blum et al. 1991; Bartelt et al. 1991). They are highly volatile and tend to degrade 


\section{FATOPE, AL-KINDI and ABDULNOUR}

rapidly in the field. Pheromones have been used to control insect pests as physical traps, lure and kill devices, and mating disrupter.

- Physical traps: insects are lured to traps using pheromones, from where they are collected and killed. Food attractant may also be used to lure insects to traps. In this process, some beneficial natural predators are also eliminated.

- Lure and kill: This technique is similar to mass trapping but once the insects are attracted, they are not entrapped but rather made to contact toxic or sterilizing agents which effectively eliminate them from the population. The kill insecticide may be dispensed or formulated as sticky droplets. A common insecticide used in a trap is pyrethroid deltamethrin.

- Mating disruption: In this technique, pheromones are used to attract and confuse male and female insects, thus making mating impossible.

Commercially useful products based on semiochemicals have been developed by Novartis for the control of Pectinophora gossypiella in cotton and Cydia pomonella in apples (Angst et al. 1990).

\section{Genetic Manipulation of Organisms for Bioactive Metabolites}

The metabolites produced by plants and microbes are closely linked to their ability to utilize various biosynthetic precursors. This ability is governed to a large extent by the genetic make up of the organism. The methods of manipulating the genes of microbes and plants have been with us for quite sometime. Traditionally, strains of microorganisms that accumulate useful metabolites of commercial interest were achieved by mutation and selection and not by direct manipulation of genes. The process is not very predictive and requires repetitive cycles of directed mutation and analysis in order to optimize a useful trait or product. In the same way, traditional plant breeding has been used to produce plants with particular phenotypic traits. It is a repetitive process of selective elimination of undeserved traits, and the product could be unpredictable as well. In 1987, Heinz G. Floss made a case for creating novel "hybrid antibiotics" by direct manipulation of industrial microorganisms. This vision is now being fulfilled in the use of combinatorial biosynthesis to make novel polyketides (Alvarez et al. 1996) and cephalosporin antibiotics in different Streptomyces species (Crawford et al. 1995), and derivatives of morphine and codeine in E. coli (French et al. 1995). The use of technology for plant transformation is also growing rapidly. Today slow softening Flavr-Savr ${ }^{\circledR}$ tomato, fiber-producing insect resistant cotton plants, maize, apple, sweet potato, and oilseed rape are cultivated in USA, and transgenic cucumber, and mosaic resistant tobacco in China (Dale, 1995; Schuler et al. 1998) to mention a few. The manipulation of organisms to express desired traits may be a natural research stategy in the millennium for natural products chemist and molecular biologist. Thus, it is appropriate to explain, in the most elementary form, the principles involved in genetic manipulation of microbes and plants.

\subsection{Method for Expressing Foreign Genes in Microbes}

DNA, the hereditary material, is found in all organisms with the exception of some viruses. Organisms perform their biochemical activities in response to instructions encoded in the DNA. New technologies now allow DNAs from one organism to be shifted into another organism where they express themselves. To achieve this, the gene (a sequence of nucleotides in a DNA molecule that specifies a particular function) is identified. Using restriction enzymes, the gene is cut out from the donor organism and inserted into plasmids. A plasmid is a special kind of bacteria DNA. It is found in the cytoplasm of bacteria. DNA ligases may be used to cut open a plasmid, donor genes are spliced into it and then integrated into the cyclic plasmid loop. The recombined plasmid is inserted into a host organism. Once inside the host organism, the plasmid replicates producing their exact copies or clones. The host organism 


\section{RESEARCH TRENDS IN NATURAL PRODUCTS}

or bacteria thus serves as a factory or bioreactor for producing the product expressed by the inserted gene. An application of this technology has been demonstrated in the production of microbial metabolites for improved biocontrol of plant pathogens (Dowling and O'Gara, 1994). It has also been adopted as a strategy for extracting genetic information from unculturable organisms (see Section 3). This technology, now dubbed combinatorial biosynthesis, may be summarized in the following general steps.

- Genomic DNAs are extracted from soil or samples collected from extreme environments (Cullen and Hirsh 1998).

- The genetic materials are encapsulated in artificial plasmids, the Bacteria Artificial Chromosome Vector (BAC) and expressed in culturable organisms e.g., Escherichia coli (BAC is a special liposome that can accept large insertions of DNA).

- The recombinant organisms are fermented, the broth extracted and screened for new bioactive compounds.

The major challenges of this approach include obtaining enough pieces of clean DNAs and genes that could code for metabolites that the host organism can express. It is now possible to identify the gene clusters that are critical to the biosynthesis of some antibiotics, modify and functionally re-express them in another organism to produce a new library of natural products (McDaniel et al. 1993 and 1995).

\subsection{Methods for Expressing Foreign Genes in Plants}

The cloning of entire biosynthetic processes in prokaryotes is rather difficult and remains elusive in plants. This is because the biosynthesis of a metabolite may be controlled, not just by one or two genes as in prokaryotes, but by a complex dozen of genes, promoter, suppressors or terminators residing in a chromosome (units into which genetic materials are packaged in an organism). A number of chemical, electrical and physical methods are used for direct gene transfer (Barcelo and Lazzeri 1998). The principles of the 3 common methods for introducing foreign genes into plants are discussed below.

\subsubsection{Use of Autonomously Replicating Virus as Vectors}

The use of virus as vectors in the transfer of genes was not commercially available until about 6 years ago because of the problem of obtaining suitable plant virus-based vectors that can be manipulated without affecting the viability of the virus itself. The RNA genomes of the tobacco mosaic virus contain 'open reading frames' that can be modified to express additional genes (Dawson et al. 1989, Donson et al. 1991). The genes of interest are inserted into the viral genome and cloned DNA copies of the RNA viral genomes are transcribed in vitro to give infectious RNA. Under certain conditions the DNA copy of the RNA viral genome may be used to infect plants directly. In this approach, the introduced genes are additions not substitutions for viral genes. The modified virus is used to inoculate seedlings or leaves by rubbing innoculum on them. The infected plant will thus express the foreign gene. This method is fast. However, the germline of the plant remains unmodified and as a result the expressed traits are not heritable. The shortcoming of this approach is the difficulties of inoculating plants on a large scale and the amount of genes that the virus can add on without comprising its viability is grossly limited.

\subsubsection{Agrobacterium-Mediated Gene Transfer}

Agrobacterium tumefaciens is a Gram- phytopathogen that causes crown gall disease in susceptible dicotyledonous plants. It is a strain of bacteria with large plasmids carrying genes that can be transferred to plant cells. Two important regions for genetic information transfer are found on the plasmids of Agrobacterium. The virulence region vir-gene, which is responsible for infection, is not usually transferred to the genome of plants. The T-DNA region contains tumor-inducing genes, the $\left(\mathrm{T}_{1}\right)$, and root-inducing 
genes, the $\left(\mathrm{R}_{1}\right)$. The genes located in the T-DNA region can be transferred but they are not required in the transfer process. A heavily mutated or modified T-DNA region can still be transferred to the host plant genome (Kung and Wu 1993). The genes governing tumorigenesis are deleted from T-DNA. The desired foreign genes and appropriate markers or reporter genes that are needed for selection of modified plant cells are inserted. The modified T-DNA genes are replicated in E. coli and then transferred to Agrobacterium tumefaciens host strain carrying plasmids from which the $\left(\mathrm{T}_{1}\right)$ genes have been deleted. The re-constituted genes could be transferred to plants by smearing wounds on plant or by inoculating plant tissue cultures with modified Agrobacterium tumefaciens. Infected plant cells are selected with the help of embedded markers or reporter genes and re-generated. The regenerated plant can be used as a source of seed for subsequent generation of transformed plants. The process may be long and slow depending on the life cycle of the plant. If the process is uncontrolled, it can produce unwanted results such as gene silencing and co-suppression of the expression of the desired feature (Flavell, 1994; Finegan and McElroy 1994). The inserted genes in this approach are inheritable.

\subsection{3 'Shot gun' or Biolistic Gene Transfer}

An alternative approach for stable gene transformation, which is equally popular and developed within the past decade, is the biolistic gene transfer. In this approach, high velocity foreign DNA or gene clusters are delivered into living cells or tissue through bombardment of tissues or cells with a particle gun called a biolistic device. The process has been well detailed in several reports (Klein et al. 1987 and 1989; Wang et al. 1988; Sanford 1990). The transformed cells are cultured and the desired traits are selected and regenerated. The gene transferred by this method is inheritable.

Several transgenic plants have been produced by these techniques (Marchant et al 1998; Schuler et al. 1998). The impact of biotechnology on pesticide delivery has been extensively covered by Hammock et al. (1999). It has, for instance, allowed insecticidal proteins produced by Bacillus thuringiensis, a free-living soil bacterium, to be expressed by maize and several other plants for insect control (Huang et al 1999; Peferoen, 1997), or plants to be modified to confer resistance to herbicides (Tsaflaris 1996).

In spite of the complaints and anxiety expressed by the public over transgenic plants, it certainly offers another route for generating unnatural natural products from which hitherto unknown bioactive compounds with a novel mode of action can be exploited.

\section{Conclusions}

Natural products have been isolated from a variety of sources and the potential for discovering additional compounds from organisms in ecologically stressed terrestrial and aquatic environments is enormous. A recent survey (Cragg et al. 1997) showed that about $35 \%$ of commonly prescribed drugs contain active ingredients derived from plant and microbial sources. Roughly $60 \%$ of drugs being submitted for approval as anti-infectives have natural origin. Natural products have also provided prototypes for synthesis of new insecticides. Our understanding of the genetic control of biosynthesis is critical to commercial exploitation of therapeutic natural products. Natural products from genetically manipulated plants and crops will continue to play significant roles in the development of pest, disease and pathogen resistant crops, and in the biosynthesis of more active and better tolerated drugs. A commercially rewarding trend in natural product research is to focus our efforts on drug discovery and development. This will allow connections to be made between academia and industry, and between ethnomedical remedies and bioactive natural products. Unfortunately, our natural biodiversity is being depleted. Our wealth of ethnomedical remedies that have accumulated over the years are also being lost. The twin resources have to be protected and preserved. Drug discovery from natural sources is expensive. However, very viable alternatives are limited. The science and technology acquired in the process is great and desirable for a developing country. Compounds from natural sources have the potential of enriching our library of candidates available for biological assessment and synthesis. Techniques in molecular biology for 


\section{RESEARCH TRENDS IN NATURAL PRODUCTS}

designing high throughput assays, combinatorial biosynthesis, random shuffling of genes for biosynthesis of desired compounds, and novel isolation methods will continue to breath significant novelty into the scientific skills of young researchers. Patent protection of novel, applicable and unobvious discoveries is necessary if the exploitation of our biota is to yield financial return, which is generally a necessary requirement to facilitate more advanced development of lead molecules.

\section{Acknowledgement}

MOF is grateful to the International Foundation for Science, Stockholm for funding his work in natural products through grants $\mathrm{F} / 2018-1$ and $\mathrm{F} / 2018-2 \mathrm{~F}$.

\section{References}

ALBERS-SCHONBERG G., ARISON B. H., CHABALA J. C., DOUGLAS A. W., ESKOLA P., FISCHER M. H., LUSI S., MROZIK H., SMITH J. L. and TOLMAN R. L. 1981. Avermectins structure determination. J. Amer. Chem. Soc. 103: 4216-4221.

ALBERS-SCHONBERG G. P., BURG, R. W. M. H., MILLER T. W. C., ORMOND R. E. D. and WALLICK G. H. S. 1977. (Priority 19 April 1976) Neue anthelminthika und verfahren zu ihrer herstellung, DT Patent 2717040 A1 (Merck and Co Inc.).

ALVAREZ, M. A., FU K., KHOSLA C., HOPWOOD D. A. and BAILEY J. E. 1996. Engineered biosynthesis of novel polyketides: Properties of the whiE aromatase/cyclase. Nature Biotechnology 14: 335-338.

ANDERSON J. E., GEOTZ C. M., McLAUGHLIN J. L. and SUFFNESS M. 1991. A blind comparison of simple bench-top bioassays and human tumor cell cytotoxicities as antitumor prescreens. Phytochemical Analysis 2: 107-111.

ANGST M., GUGUMUS F., RIST G., VOGT M. and RODY J., 1990. (Priority 28 December. 1988). EP Patent 376888 A1 (Ciba-Geigy AG).

ARENA J. P., LIU K. K., PAGRESS P. S., FRAIZER E. G., CULLY D. Y., MROZIK H. and SCHSAEFFER J. M. 1995. The mechanism of action of avermectins in Caenorhabditis elegaus: Correlation between activation of glutamate-sensitive chloride current, membrane binding and biological activity. J. Parasitol. 81: 286-294.

BAKER R., HERBERT R. H., HOWSE P. E., JONES O. T., FRANKE W. and REITH W. 1980. Identification and synthesis of the major sex pheromones on the olive fruit fly (Dacus oleae) J. Chem. Soc. Chem. Commun. 5253.

BALANDRIN M. F., KINGHORN A. D. and FRANSWORTH N. R. 1993. Medicinal agents from plant. Kinghorn A. D. and Balandrin M. F. (Eds.), ACS Symposium Series 534, Americans Chemical Society, Washington DC USA pp 2-12.

BARCELO P. and LAZZERI P. A. 1998. Direct gene transfer: Chemical and physical methods. In Transgenic Plant Research Lindsey K (Ed.), Harwood Academic, Amsterdam, pp 35-56.

BARTLET R. J., DOWD O. F. and PLATTNER R. D. 1991. Aggregation pheromone of Carpophilus lugubris, New pest management tools for the Nitidulid beetles. In Naturally Occurring Pest Bioregulators. Hedin P.A. (Ed.), ACS Symposium Series 449, American Chemical Society, Washington DC, USA, pp 27-40.

BLUM M. S., EVERETT D. M., JONES T. H. and FALES H. M. 1991. Arthropod natural products as insect repellents. In Naturally Occurring Pest Bioregulators. Hedin P.A. (Ed.), American Chemical Society Symposium series 449, American Chemical Society, Washington DC, USA, pp 14-26.

BLUNDEN G. 1996. Biologically active compounds from marine organisms. In Trease and Evans' Pharmacognosy Evans W. C. (Ed.), W. B. Saunders Co Ltd, London, pp 18-27.

CAI Q., LINDSEY J. R. and ZHANG R 1997. Regression of human colon cancer xenografts in SCID mice following oral administration of water-soluble camptothecins. Int. J. Oncol. 10: 953-960.

CARDELliNA II, J. H., MUNRO M. H. G., FULLER R. W., MANFREDI K. P., McKEE T. C., TISCHLER M., BOKESCH H. R., GUSTAFSON K. R., BEUTLER J. A. and BOYD M. R. 1993. J. Nat. Prod. 56: 1123.

COHEN J. I. 1993. Apoptosis, Immunology Today 14: 126-130.

CORDELL G.A. 1995. Changing strategies in natural products chemistry Phytochemistry 40: 1585-1612. 
CRAGG G. M., BOYD M. R., CARDELliNA II J. H., GREVER M. R., SCHEPARTZ S. A., SNADER K. M. and SUFFNESS M. 1993. In Human Medicinal Agents from Plants. Kinghorn A.D. and Balandrin M.F (eds). ACS Symposium Series 534, American Chemical Society, DC,USA, pp 80.

CRAGG G. M., NEWMAN D. J. and SNADER K. M. 1997. Natural products in drug discovery and development $J$. Nat. Prod. 60: 52-60.

CRAWFORD L., STEPAN A. M., McADA P. C., RAMBOSEK J. A., CONDER M. J., VINCI V. A. and REEVES C. D. 1995. Production of cephalosporin intermediates by feeding adipic acid to recombinant Penicillium chrysogenum strains expressing ring expansion activity. Bio/Technology 13: 58-62.

CULLEN D. W. and HIRSCH P. R. 1998. Simple and rapid methods for direct extraction of microbial DNA from soil for PRC. Soil Biology and Biochemistry 30: 983-993.

DALE P. J. 1995. R and D regulation and field trailing of transgenic crops. Trends in Biotechnology 13: $398-403$.

DAWSON W. O., LEWANDOWSKI D. J., HILF M. E., BURRICK P., RAFFO A. J., SHAW J. J., GRANTHAM G. L. and DESJARDINS P. R. 1989. A tobacco mosaic virus-hybrid expresses and loses an added gene. Virology 172: 285-292.

DEY P. M. and HARBORNE J. R. (Eds). 1991 Methods in Plant Biochemistry, Volume 6, Academic Press, London, $351 \mathrm{pp}$.

DEYFUSS, M. M. and CHAPELA, I. H. 1994. In Discovery of Natural Products with Therapeutic Potential. Edit. Gullo V. P ; Butterworth-Heinemann, Boston pp 49-80.

DONSON J., KEARNEY C. M., HILF M. E. and DAWSON W. O. 1991. Systemic expression of a bacterial gene by a tobacco mosaic virus-based vector. Proc. Natl. Acad. Sci. USA. 88: 7204-7208.

DOWLING D. W. and O'GARA F 1994. Metabolites of Pseudomanas involved in the biocontrol of plant disease TIBECH 12:133-141.

ELLIOTT M. In Crop Protection Agent from Nature: Natural Products and analogues. Copping L.G. (Ed) Royal Society of Chemistry, Cambridge, 1996, pp 254.

FAULL J. L. and POWELL K. A., 1995. Biological control agents. In Agrochemical from Natural Products. Godfrey C. R. A. (Ed.), Marcel Dekker, New York, pp 369-393.

FAULKER D. J. 1995. Marine natural products. Natural product Report 12: 75-125.

FATOPE M. O. 1995. Phytocompounds: Their bioassay and diversity. Discovery and Innovation 1: 229-236.

FINNEGAN J. and McELROY D. 1994. Transgene inactivation: Plants fight back. Bio/Technology 12: 883-888.

FLAVELL R. B. 1994. Inactivation of gene expression in plants as a consequence of specific sequence duplication. Proc. Natl. Acad. Sci. USA. 91: 3490-3496.

FISHER D. E. 1994. Apoptosis in cancer therapy: Crossing the threshold. Cell 78: 539-542.

FOA R., NORTON L. and SEIDMAN A. D. 1994. Taxol (paclitaxel): A novel anti-microtubule agent with remarkable anti-neoplastic activity. Int. Journal of Clinical and Laboratory Research 24: 6-14.

FRENCH-CHRISTOPHER E., HAILES, A. M., RATHBONE D. A., LONG M. I., WILLEY D. L. and BRUCE N. C. 1995. Biotechnology New York 13: 674-676.

HAIN R. 1999. Modification of plant secondary metabolism by foreign phytoalexin genes. In Pesticide Chemistry and Bioscience. The Food-environment challenge. Brooks G. T and Roberts T. R (Eds). The Royal Society of Chemistry Special Publication No 233: pp 190-203.

HAIN R., REIF H. F., KRAUSE E., LANGEBARTELS R., KINDL H., VORNAM B., SCHMELZER W. E., SCHREIER P. H., STOCKER R. and STENZEL K. 1993. Disease resistance results from foreign phytoalexin expression in novel plant. Nature 361: 153-156.

HAMMOCK B. D., INCEOGLU A. B., RAJENDRA W., FUXA J. R., CHEJANOUSKY N., JARVIS D., and HNZLIK T. M. 1999. Impact of biotechnology as pesticide delivery. In Pesticide Chemistry and Bioscience. The Food Environment Challenge. Brooks G.T and Roberts T.R. (Eds.), The Royal Society of Chemistry. Special Publication 233: pp 74-99.

HASEGWA S., KODAMA F., KANESHIMA H. and AKAI J. 1986. Biological control of Fusarium wilt of adzukibean caused by Fusarium oxysporum. Report of the Hokkaido Institute of Public Health. 36: 16-23.

HEDIN P. A. and MENN J. J. (Eds). 1988. Insect chemical communication. unifying concepts. Special Issue, J. Chem. Ecology 14:1979-2145.

HENRICK C. A. 1995. In Agrochemical from Natural Products Godfrey C. R. A. (Ed) Marcel Dekker, New York, pp 63.

HERBERT R. B. 1989. The Biosynthesis of Secondary Metabolities, $2^{\text {nd }}$ Edition, Chapman and Hall, London, $231 \mathrm{pp}$.

HICK A. J., LUSZNAIR M. C. and PICKETT J. A 1999 . Volatile isoprenoids that control insect behaviour and development. Nat. Prod. Report 16: 39-54. 


\section{RESEARCH TRENDS IN NATURAL PRODUCTS}

HOEHN M. M. and MICHEL K. H. 1990 (Priority 12 May 1989) Macrolide antibiotic. EP 0398588 A1 (Eli Lilly and Company).

HONG W. K. and SPORN M. B. 1997. Recent advances in chemoprevention of cancer. Science 278: 1073-1077.

HOWELL C. R. and STIPNOVIC R. D. 1980. Suppression of Pythium ultimum - induced damping-off of cotton seedlings by Pseudomonas flurorescens and its antibiotic, pyoluteroin. Phytopathology 70: 712-715.

HUANG F., BUSCHMANN L. L., HIGGINS, R. A. and McGAUGHEY W. H. 1999. Inheritance of resistance to Bacillus thuringiensis toxin (Dipel ES) in the european corn borer. Science 284: 965-967.

JACOBSON M. 1989 Botanical pesticides, past present and future. In Insecticides of Plant Origin. Arnason J. T, Philogene B. J. R. and Morand (Eds) ACS Symposium Series 387 American Chemical Society, Washington DC, USA $1-10$.

JACOBSON M. 1971 In Naturally Occurring Insecticides. Jacobson M. and Crosby D.G (Eds.), Marcel Dekker New York, 137.

JANG M., CAI L., UDEANI G. O., SLOWING K. V., THOMAS C. F., BEECHER, C. W. W., FONG H. H. S., FARNSWORTH N. R., KINGHORN A. D., MEHTA R. G., MOON R. C. and PEZZUTO J. M. 1997. Cancer chemopreventive activity of resveratrol, a natural product derived from grapes. Science 275: $218-220$.

JONES O. T. 1994. The current use of pheromones in the integrated management of insect pests. Pesticide Outlook 5: 26-31.

KANAVAGH F. 1963. In Analytical Microbiology (Kanavagh F (Ed) pp 125 - 141. Academic Press, London.

KEEL C., WIRTHNER P., OBERHANSLI T., VOISARD C., BURGER U., HAAS D. and DEFAGO G. 1990. Pseudomonads as antagonists of plant pathogens in the rhizosphere: Role of antibiotic 2,4-diacetylphloroglucinol in the suppression of black rot of tobacco. Symbiosis 9: 327-341.

KINGHORN A. D. and BALANDRIN M. F. (Eds.). 1993. Human Medicinal Agents from Plants. ACS Symposium Series 534 American Chemical Society, Washington DC, USA.

KINGHORN A. D., FONG H. H. S., FARNSWORTH N. R., MEHTA R. G., MOON R. C., MORIARTY R. M. and PEZZUTO J. M. 1998. Cancer chemopreventive agents discovered by activity-guided fractionation: A review. Current Organic Chemistry 2: 597-612.

KLEIN T. M., ROTH B. and FROMM M. E. 1989. Regulation of anthocyanin biosynthetic genes introduced into intact maize tissues by microprojectiles. Natl. Proc. Acad. Sci. USA. 86: 6681-6685.

KLEIN T. M., WOLF E. D., WU R. and SANFORD J. C. 1987. High-velocity microprojections for delivering nucleic acid into living cells. Nature 327: 70-73.

KIRST H. A., MICHAEL K. H., MARTIN J. W., CREEMER L. C., CHIO E., YAO R. C., NAKATSUKASA W. M., BOECK L. D., OCCOLOWITZ J. L., PASCHAL J. W., DEETER J. L., JONES N. D. and THOMPSON G. D. 1991. A83543A-D: Unique fermentation-derived tetracycline macrolides. Tetrahedron Lett. 32: 4839-4832.

KNAUSS J. F. and WALTER J. F. 1995 In The Neem Tree, Azadirachta indica A., Juss and other Meliaceous plants. Schmutterer H. (Ed.), VCH, Weinheim ,437.

KUNG SHAIN-D and Wu R. 1993. (Eds.), Transgenic Plants. Vol. 1, Engineering and Utilization. Academic Press Inc., New York, .383.

LANZ T., SCHRODER G. and SCHRODER J. 1990. Differential regulation of genes for resveratrol synthase in cell cultures of Arachis hypogaea L. Planta 181: 169-175.

LEE S. K., MBWAMBO Z. H., CHUNG H. S., LUYENGI L., GANEZ E. J. C., MEHTA R. G., KINGHORN A. D. and PEZZUTO J. M. 1998. Evaluation of antioxidant potential of natural products. Combinatorial Chemistry and High Throughput Screening 1: 35-46.

LEE S. K., SONG L., MATA-GREENWOOD E., KELlOFF G. J., STEEL V E. and PEZZUTO J. M. 1999. Modulation of in vitro biomarkers of the carcinogenic process by chemopreventive agents. Anticancer Res. 19: 35-34.

LIGON J. M., HILL D. S., HAMMER P., TORKEWITZ N., HOFMANN D., KEMPF H. J and VAN PEE K-H. 1999. Natural Products with antimicrobial activity from Pseudomanas biocontrol bacteria. In Pesticide Chemistry and BioScience. The food-environment Challenge. Brooks G. T. and Roberts T. R (Eds). Royal Society of Chemistry, Special Publication No 233: pp 179-189.

LUNDHOLM N., SKOV J., POCKLINGTON R. and MOESTRUP O. 1994. Domoic acid, the toxic amino acid responsible for amnesic shellfish poisoning, now in Pseudonitzschia seriata (Bacillariophyceae) in europe. Phycologia 33: 475-478.

MARCHANT R., POWER J. B., LUCAS J. A. S. and DAVEY M. R. 1998 Biolistic transformation of rose (Rosa hybrid. L) Annals of Botany 81: 109-114.

MARSTON A. and HOSTETTMANN K. 1991. Modern Separation Methods Natural Products Reports 391-413. 


\section{FATOPE, AL-KINDI and ABDULNOUR}

MANN J. 1992. Murder, Magic and Medicine. Oxford, University Press. Oxford UK, 232 pp.

MASSIOT G., LAVAND G. and NUZILLARD J. M. 1999. Structure elucidation of plant secondary products. In Chemicals from Plants: Perspectives on Plant Secondary Products, Walton N. I. and Brown D. E. (Eds) World Scientific Publishing Co PTE (Ltd), pp. 187-214.

MAY W. S., SHARKIS S. J., ESA A. H., GEBBIA V., KRAFT A. S., PETTIT G. R. and SENSENBRENNER L. L. 1987. Antineoplastic bryostatins are multipotential stimulators of human hematopoietic proginator cells. Proc. Natl. Acad. Sci. USA. 84: 8483-8487.

McCONNELl O. J., LONGLEY R. E. and KOEHN F. E. 1994. In The Discovery of Natural Products with Therapeutic Potential Gullo V. (Ed.), Butterworth-Heinemann Boston, pp 109-174.

McDANIEL R., EBERT-KHOSLA S. and HODWOOD D. A. 1995 . Rational design of aromatic polyketide natural products by recombinant assembly of enzyme subunits. Nature (London) 375: 549-554.

McDANIEL R., KHOSLA E., HOPWOOD D. A. and KHOSLA C. 1993. Engineered biosynthesis of novel polyketides. Science 262: 1546-1550.

McLAUGHLIN J. L. 1991. Crown gall tumors on potato discs and brine shrimp lethality. Two simple bioassays for higher plant screening and fractionation. In Methods in Plant Biochemistry Dey P. M. and Harborne J. R. (Eds.) Vol 6, Academic press, New York, pp 1-32.

MEHTA R. G., LIU J., CONSTANTINOU A., THOMAS C. F., HAWTHORNE M., YOU M., GERHAUSER C., PEZZUTO J. M., MOON R. C. and MORIARTY R. M. 1995. Cancer chemopreventive activity of brassinin, a phytoalexin from cabbage. Carcinogenesis 16: 399-404.

MITSCHER L. A., DRAKE S., GOLLAPUDI S. R. and OKWUTE S. K. 1987. A modern look at folkloric use of antiinfective agents. J. Nat. Prod. 50: 1025-1040.

MULBRY W. and RAININA E. 1999. Biodegradation of chemical warfare agents. Chemistry International 21: 173178.

NICOLSON G. L. 1988. Organ specificity of tumor metastasis: Role of prefential adhesion, invasion and growth of malignant cells at specific secondary sites. Cancer and Metastasis Reviews 7: 143-188.

PACHLATKO J. P. 1998. Natural Products In crop Protection. Chimia 52: 29-47.

PEFEROEN M. 1997. Progress and prospects for field use of Bt genes in crops Trends in Biotechnology 15: 173-177.

PETTIT G. R., PIERSON H. T. and HERALD C. L., 1994. Anti-cancer drugs from animals, plants and microorganisms, John Wiley and Sons, New York.

PEZZUTO J. M. 1995. Natural product cancer chemopreventive agents. In Recent Advances in Phytochemistry, 29: Phytochemistry of medicinal plants, Arnason J. T., Mata R. and Romeo J. T. (Eds.), Penum press, New York, pp $19-45$.

POSTE G. and FIDLER I. J. 1980. The pathogenesis of cancer metastasis. Nature 283:139-146.

RIOS J. L., RECIO M. C. and VILLAR A. 1988. Screening methods for natural products with antimicrobial activity: A review of the literature. J. Ethnopharmacol 23: 127-149.

RODRIQUEZ E. 1983. In Plant Resistant to Insects. Hedin P.A (Ed.), ACS Symposium series No 208, American Chemical Society, Washington DC, USA, 291-302.

SCHIPPERS G., BAKKER A. W. and BAKKER P.A. H. M. 1987. Interactions of deleterious and beneficial microorganisms and the effect of cropping practices. Annu. Rev. Phytopathol 25: 339-358.

SCHMITZ F. J., BOWDEN B. F. and TOTH S. I. 1993. Antitumor and cytotoxic compounds from marine organism. In Marine Technology Vol 1. Pharmaceutical and Bioactive Natural Products. Attaway D. H. and Zaborsky O.R (Eds.), Plenum Press, New York, pp. 197-308.

SCHROTH M. N. and HANCOCK J. G. 1982. Disease-suppressive soil and root-colonizing bacteria. Science 216: 1376-1381.

SCHULER T. H., POPPY G. M. KERRY B. R. and DENHOLM I. 1998. Insect resistant transgenic plants. Trends in Biotechnology 16: 168-175.

SHIMIZU Y. 1993. Microalgal metabolites Chem. Rev. 93: 1685-1698.

SHIMIZU Y. 1993. In Marine Biotechnology Attaway D. H. and Zaborsky O. R. (Eds.), Plenum Press, New York Volume 1, 391-410.

STELLER H. 1995. Mechanisms and genes of cellular suicide. Science 267: 1445-1449.

SUFFNESS M. and PEZZUTO J. M. 1991 Assays related to Drug Discovery. In Methods in Plant Biochemistry Vol. 6. Hostettmann K (Ed). Academic Press, London, pp. 71-133.

TAWARA S., MATSUMOTO S., HIROSE T., MATSUMOTO Y., NAKAMOTO S., MITSUNO M. and KAMIMURA T. 1989. In vitro antifungal synergism between pyrrolnitrin and clotrimazole. Japan J. Med. Mycol. 30: 202-210. 


\section{RESEARCH TRENDS IN NATURAL PRODUCTS}

TSAFFARIS A. 1996. The development of herbicide-tolerant transgenic crops. Field Crop Res. 45: 115-123.

UDEANI G. O., GERHAUSER C., THOMAS C. F., MOON R. C., KOSMEDER J. W., KINGHORN A. D., MORIARTY R. M. and PEZZUTO J. M. 1997. Cancer chemopreventive activity mediated by deguellin, a naturally occurring rotenoid. Cancer Res. 57: 3424-3428.

UMIO S., KAMIMURA T., KAMISHITA T., and MINE Y. 1986. Antifungal composition employing pyrrolnitrin in combination with an imidazole compound. US Patent 4, 636, 520.

VAN BEER T. A. 1999. Modern methods of secondary products In Chemicals from Plants, Perspectives on Plant Secondary Products Walton N. J. and Brown D. E (Eds) World Scientific Publishing Co PTE (Ltd) pp. 91-186.

WALL M. E. and WANI M. C. 1995 In Alkaloids Chemical and Biochemical Perspectives Pelletier S. W (Ed.), Volume 9. Pergamon UK pp 2.

WANG Y-C., KLEIN T. M., FROMM M., CAO J., SANFORD J. C., and WU R. 1988. Transient expression of foreign genes in rice, wheat and soybean cells following particle bombardment. Plant Molecular Biology 11: 433-439.

WELLER D. M. 1988. Biological control of soil-borne plant pathogens in the rhizosphere with bacteria. Annu. Rev Phytopathol 26: 379-407.

WYLLIE A. A. 1995. The genetic regulation of apoptosis. Current Opinion in Genetics and Development 5: 97-104.

ZHANG B., SALITURO G., SZALKOWSKL D., LI Z., ZHANG Y., ROYO I., VILELLA D., DIEZ M. T., PELAEZ F., RUBY C., KENDALL R. L., MAO X., GRIFFIN P., CALAYCAY J., ZIERATH J. R., HECK J. V., SMITH R. G. and MOLLER D. E. 1999. Discovery of small molecule Insulin mimetic with antidiabetic activity in mice. Science 284; 974-977.

Received 24 January 2000

Accepted 12 June 2000 